\title{
Consumer Ethnocentrism: Reconceptualization and Cross-cultural Validation
}

\author{
Piyush Sharma ${ }^{1}$
}

\begin{abstract}
Consumer ethnocentrism (CE) is a popular construct in international marketing research and is generally measured using the CETSCALE, a reliable scale with proven predictive validity but with limited evidence about its construct validity, dimensionality and crosscultural measurement invariance. This note addresses these gaps by reconceptualizing CE as an attitude construct consisting of three dimensions: 1) affective reaction, 2) cognitive bias and 3) behavioral preference. A revised CE Scale (CES) is developed and tested using two empirical studies with adult consumers from four different countries (China, India, UK and USA), showing that CES is a reliable, valid and cross-culturally invariant scale and it explains greater variance than the CETSCALE and other similar scales, in customer evaluations and behavioral intentions for a wide range of products and services.
\end{abstract}

Keywords: Consumer ethnocentrism, CETSCALE, animosity, patriotism, internationalism, cosmopolitanism

\section{Author's Brief Bio:}

Piyush Sharma is a Professor in the School of Marketing at Curtin University in Australia. His research covers services and international marketing, cross-cultural consumer behavior, counterfeit consumption and self-regulation; and is published in the Journal of International Business Studies, Journal of the Academy of Marketing Science, Journal of Service Research, Journal of Business Research, European Journal of Marketing, among others.

${ }^{1}$ Professor, School of Marketing, Curtin Business School, Curtin University, Bentley, WA 6102, Australia. Phone: +61 (8) 9266 3744, Fax: +61 (8) 9266 3937, Email: piyush.sharma@curtin.edu.au) 


\section{Consumer Ethnocentrism: Reconceptualization and Cross-cultural Validation}

\section{INTRODUCTION}

Shimp and Sharma (1987: p.280) define 'Consumer Ethnocentrism' (CE) as “the beliefs held by consumers about the appropriateness, indeed morality, of purchasing foreign made products" such that high ethnocentric consumers refuse to buy imported products and may even chastise others for doing so. Since then, CE has become a popular construct with numerous studies using the CETSCALE and its many versions, to show that $\mathrm{CE}$ has a negative effect on the evaluation of foreign products and a positive effect on preference for domestic products. However, despite CE being described as a set of beliefs (Shimp and Sharma 1987: p.280), a tendency (Shimp and Sharma 1987: p.281) or even like a trait (Sharma, Shimp \& Shin 1995: p.27), most items in CETSCALE seem to represent its broad socionormative and economic aspects, highlighting the need to support American products while rejecting foreign products because of their harmful effect on American economy.

Specifically, most items in CETSCALE either prescribe what American consumers should do (e.g., \#1: American people should always buy American products, \#7: A real American should always buy American-made products, and \#9: It is always best to purchase American products) or explain what is wrong with buying foreign products (e.g., \#5: Purchasing foreign-made products is un-American, and, and \#11: Americans should not buy foreign products because this hurts American businesses and causes unemployment) or suggest what should be done about foreign products (e.g., \#12 Curbs should be put on all imports). In contrast, only one of the 17 items in CETSCALE (\#13: It may cost me in the long run but I prefer to support American products) actually seems to tap into an individual consumer's own personal beliefs or tendencies, as envisaged by Shimp and Sharma (1987) in their conceptual definition of CE.

This is an important disconnect between the conceptual definition of CE and its operationalization, which has been ignored by subsequent researchers and they continue to use CETSCALE and its various versions in their studies around the world. In addition, an over-emphasis on the socio-normative and economic aspects that may change drastically with time (rather than individual 
socio-psychological elements that may be more enduring), is likely to further limit the 'applicability' and 'generalizability' of CETSCALE across countries with different levels of economic development and dependence on foreign products as well as its 'stability' as both these factors may change over time.

Notwithstanding the above limitations of CETSCALE, most international researchers have simply assumed CE to have the same conceptual meaning and operational structure in other countries as in USA where it was originally developed (e.g., Ang, Jung, Kau, Leong, Pornpitakpan, \& Tan, 2004; Durvasula, Andrews, \& Netemeyer, 1997; Good \& Huddleston, 1995; Jo, 1998; e.g., Johansson, Ronkainen, \& Czinkota, 1994; Pereira, Hsu, \& Kundu, 2002; Reardon, Miller, Vida, \& Kim, 2005; Sharma, Shimp, \& Shin, 1995; Suh \& Kwon, 2002). In addition, most studies that collected data from multiple countries using CETSCALE do not test its measurement invariance . Even studies that address this issue, neither tested all the levels of invariance for the full CETSCALE nor established its dimensionality (e.g., Cleveland, Laroche, \& Papadopoulos, 2009; Klein, Ettenson, \& Krishnan, 2006; Kwak, Jaju, \& Larsen, 2006; Netemeyer, Durvasula, \& Lichtenstein, 1991; Sharma, 2010; Steenkamp \& Baumgartner, 1998; Steenkamp, Hofstede, \& Wedel, 1999).

Finally, most studies in USA have found the full CETSCALE to be unidimensional but others have discovered more than one dimension, such as in Australia (Acharya \& Elliott, 2003), China and Taiwan (Hsu \& Nien, 2008), Greece (Chryssochoidis, Krystallis, \& Perreas, 2007), India (Bawa, 2004; Khan \& Rizvi, 2008; Kinra, 2006; Upadhyay \& Singh, 2006), Netherlands (Douglas \& Nijssen, 2003), Poland (Marcoux, Filiatrault, \& Chéron, 1997; Supphellen \& Rittenburg, 2001), and Russia (Supphellen \& Grønhaug, 2003). Hence, there is no consensus on the conceptual and empirical structure of CE and its applicability across different countries, product categories and consumer characteristics. To overcome these problems, many studies use shorter versions of the original CETSCALE introduced by Shimp and Sharma (1987); however this raises concerns about its conceptual equivalence and construct validity.

To summarize, the CETSCALE is clearly a popular and reliable scale with proven ability to predict purchase intentions and actual purchase behavior towards domestic vs. foreign products across a diverse range of product categories in several countries around the world. However, there is limited 
evidence about its validity, dimensionality, and cross-cultural measurement invariance, which may be responsible for the mixed findings about the antecedents and consequences of CE reported in studies conducted outside USA. There is also little research on the influence of CE across a wider range of domestic vs. foreign products and services.

This paper addresses all the above gaps. First, based on an extensive review of international marketing and cross-cultural social-psychology research, the author reconceptualizes CE as a multidimensional 'attitude' construct with three dimensions: 1) affective reaction (affinity for domestic products and aversion towards foreign products), 2) cognitive bias (evaluative bias in favor of domestic products), and 3) behavioral preference (rejection of foreign products and acceptance of domestic products). Next, the author develops and tests a revised CE Scale (CES) to measure these dimensions using well-established scale development procedures and uses two empirical studies with consumers in four different countries to test its reliability, validity, cross-cultural measurement invariance and influence on consumer evaluations and behavioral intentions for five products and services categories each.

\section{THEORETICAL BACKGROUND}

$\mathrm{CE}$ represents a preference for domestic products and abhorrence towards foreign products (Shimp \& Sharma, 1987). It originates from the general concept of ethnocentrism characterized by a favorable bias towards one's own group (in-group) versus others (out-group), and consists of the following properties: 1) distinction among different groups; 2) biased perception about events that favor own group's interests; 3) perception about own group as the center of the universe; 4) suspicion and disdain for other groups; 5) perception about own group as being superior, strong, and honest; and 6) perception about other groups as being inferior, weak and dishonest (LeVine \& Campbell, 1972).

However, it is not clear if the CE construct, as conceptualized and operationalized by Shimp and Sharma (1987), adequately represents the conceptual definition of ethnocentrism. Specifically, they argue that CE consists of three characteristics: 1) it results from love and concern for one's country and the fear of losing one's economic interests due to imports; 2) intention or willingness to prefer domestic products 
over imported products; and 3) a personal level of prejudice towards imported products. All these characteristics seem to emphasize individual attitudes and behaviors towards 'imported products' and not a broad trait that may manifest its ethnocentric tendency in other consumption contexts and yet their CETSCALE consist of items that mostly represent the socio-normative and economic issues related to the American consumers' general response to foreign and American-made products.

As admitted by Shimp and Sharma (1987, p. 281), they were trying to develop a scale to measure a general construct of 'consumer orientations toward foreign products', with seven dimensions and CE as only one of those dimensions. However, they found the other six dimensions unreliable, so they decided to focus on the ethnocentrism dimension and developed it further to reflect 'consumer attitudes' towards domestic versus foreign products. In fact, they found only 12 items for the CE dimension to be reliable but decided to include 5 items that were earlier found unreliable, resulting in a 17 -item final scale. Hence, it is not surprising to see that many subsequent studies found two or more factors for the CETSCALE when they tried to replicate Shimp and Sharma's (1987) results (e.g., Acharya \& Elliott, 2003; Bawa, 2004; Chryssochoidis et al., 2007; Douglas \& Nijssen, 2003; Hsu \& Nien, 2008; Khan \& Rizvi, 2008; Kinra, 2006; Marcoux et al., 1997; Supphellen \& Grønhaug, 2003; Supphellen \& Rittenburg, 2001; Upadhyay \& Singh, 2006). However, this important aspect about the CE construct has been largely ignored by researchers as they continue to use it without testing its conceptual and measurement invariance in the context of their own studies.

$\mathrm{CE}$ is a "trait-like property of individual personalities" that may influence consumers' attitudes and behavior towards domestic versus foreign products but is a different construct from both of them (Sharma et al., 1995, p.27). However, a look at Shimp and Sharma's (1987) 17-item CETSCALE shows that most of these items relate to broad social norms towards purchase of domestic versus foreign products in the USA and their impact on the American economy, which may possibly explain the strong correlation between CETSCALE scores and consumer attitudes or behavior (e.g., Durvasula et al., 1997; Good \& Huddleston, 1995; Jo, 1998; Pereira et al., 2002; Reardon et al., 2005; Suh \& Kwon, 2002), although it does raise concerns about the discriminant validity between $\mathrm{CE}$, attitudes and behavior. 
Prior research on attitudes defines them as "a relatively enduring organization of beliefs, feelings, and behavioral tendencies towards socially significant objects, groups, events or symbols" (Vaughan \& Hogg, 2005) or "a psychological tendency that is expressed by evaluating a particular entity with some degree of favor or disfavor" (Eagly \& Chaiken, 1993). LaPiere (1934) introduced a three-component $\mathrm{ABC}$ structure for attitudes - 1) affective component representing a person's feelings or emotions about the attitude object; 2) behavioral component related how attitudes influence how we act or behave; and c) cognitive component that involves a person's beliefs or knowledge about an attitude object.

In view of the above, the author argues that $\mathrm{CE}$ represents 'an overall attitude towards domestic and foreign products and services consisting of affective reaction, cognitive bias and behavioral preference' and uses the above $\mathrm{ABC}$ structure to reconceptualize $\mathrm{CE}$ as a three-dimensional 'attitude' construct with affective, cognitive and behavioral aspects, as follows:

1) Affective reaction: Ethnocentrism not only involves making a distinction between own group and others, but is also accompanied with suspicion and disdain for other groups. This may explain why high ethnocentric consumers show an affinity for domestic products and aversion for foreign products, irrespective of their respective quality. In other words, CE has a distinct affective dimension, which has been called 'emotional' (Acharya \& Elliott, 2003) or 'soft' ethnocentrism (Chryssochoidis et al., 2007; Teo, Mohamad, \& Ramayah, 2011).

2) Cognitive bias: A cognitive bias in the perceptions about in-group versus out-group is an integral part of ethnocentrism (LeVine \& Campbell, 1972). These biases include perceptions about events that favor own group's interests and about the importance, superiority, strength, and virtues of own group compared to others. Prior research on CE shows evidence for this as an evaluation bias in favor of domestic products compared to the imported products and services.

3) Behavioral preference: Rejection of foreign products and acceptance of domestic products is the most important element of CE (Shimp \& Sharma, 1987). Hence, it is included as the third dimension of the CE construct. However, it goes beyond the preference for purchase of domestic 
products over imported products as highlighted by Shimp and Sharma (1987), and extends its scope to other behavioral aspects such as willingness to try, repeat purchase and positive WOM.

\section{SCALE DEVELOPMENT AND VALIDATION}

\section{Study 1 - Scale Development}

To ensure that the new CE scale represents individual socio-psychological elements shared by consumers across different countries with varying levels of economic development and diverse cultural values, the author began with an exhaustive review of international marketing research with consumers in countries all over the world, to generate an initial pool of 36 items. Next, four independent judges (one from each country included in this study (namely China, India, UK and USA) reviewed and helped reduce these to 24 items with eight items for each dimension as recommended by Hardesty and Bearden (2004). Next, data from a mall-intercept survey of retail shoppers in four countries - China, India, UK and USA $(\mathrm{N}=1056)$ was used to assess the psychometric properties of the 24 items, which further helped test the face and content validity of all the items in each of these four countries.

Using exploratory factor analysis, six items (two from each dimension) were eliminated due to factor loadings below 0.40 and item-to-total correlations below 0.50 (Nunnally, 1978). The remaining 18 items load on three factors, explaining $73 \%$ variance in the data $(42 \%, 18 \%$, and $13 \%)$ with six items loading significantly on each of the three factors, named affective reaction, cognitive bias and behavioral preference. Next, each set of six items was used as a sub-scale to test its individual reliability as well as for the full 18-item reduced scale. All the scales showed high reliability (Cronbach's $\alpha=0.80$ to 0.86 ) and the average scores for each sub-scale were found normally distributed with adequate variance. Similar results were obtained with individual samples from all the four countries.

\section{Study 2: Scale Validation}

This study also used a mall-intercept survey of retail shoppers in four countries $(\mathrm{N}=1448)$, similar in profile to first study. Participants first evaluated five categories of domestic and foreign 
products (family car, notebook computer, home furniture, luxury watch and fine wine) and services (air travel, retail banking, call center, holiday resort and personal healthcare) and indicated their behavioral intentions (trial, purchase, positive WOM). Next, they completed scales for consumer animosity (Klein, Ettenson, \& Morris, 1998), national identification (Verlegh, 2007), patriotism, nationalism, and internationalism (Balabanis, Diamantopoulos, Mueller, \& Melewar, 2001), cosmopolitanism (Cleveland et al., 2009) and CETSCALE (Shimp \& Sharma, 1987) along with the new CE scale, to help test its validity, dimensionality and measurement invariance.

Confirmatory factor analysis shows a good fit $\chi^{2}=5980.44, d f=3477, \chi^{2} / d f=1.72, \mathrm{NFI}=.91$, $\mathrm{CFI}=.96, \mathrm{RMSEA}=.048, \mathrm{SRMR}=.059)$ based on the recommended cut-off values for various fit indices (Hu \& Bentler, 1999; Wheaton, Muthen, Alwin, \& Summers, 1977). All items load highly (> $0.60)$ on their respective factors with no major cross-factor loadings $(<0.40)$ and high t-values $(>9.88, \mathrm{p}$ $<0.001)$. All parameter estimates $(\lambda)$ are significantly different from zero at the $5 \%$ level, showing high convergent validity; and none of the confidence intervals of the correlation coefficients for each pair of scales ( $\Phi$ estimates) includes 1.0, showing discriminant validity (Anderson \& Gerbing, 1988). Average variance extracted by each factor (including each component of the revised CE Scale) exceeds the square of its correlations with each of the other factors and 0.50 , as further evidence of discriminant validity (Fornell \& Larcker, 1981). Moreover, squared multiple correlations for all the scale items are above 0.40, and construct reliabilities range from 0.82 to 0.88 ; hence all the scales are reliable (Bagozzi \& Yi, 1988). Similar results were obtained for the individual samples from the four countries. Thus, affective reaction, cognitive bias and behavioral preference provide three reliable and valid dimensions of revised CE scale.

$<$ Insert Table 1 about here $>$

Cross-cultural measurement invariance was tested using the multi-step procedure recommended by Steenkamp and Baumgartner (1998) to test the three-dimensional structure for the samples from the four countries (China, India, UK and USA). The results show full configural, factor covariance and factor variance invariance and only partial metric, scalar and error variance invariance for CES (Table 1). 
Hence, the new CE scale shows a similar pattern of factor loadings and correlations among the factors across the four groups, which allows reliable cross-cultural comparison of difference scores, factor means, correlations and regression coefficients (Steenkamp \& Baumgartner, 1998). Table 2 shows the three components of the revised CE scale with all the scale items.

$<$ Insert Table 2 about here $>$

Nomological validity was assessed by examining the phi $(\Phi)$ estimates and showing that the scores for the new consumer ethnocentrism scale and its three sub-scales correlate with other measured constructs, in the expected directions (Table 3). As expected, CE correlates positively with the CETSCALE $(r=0.42, p<0.001)$, consumer animosity $(r=0.14, p<0.01)$, national identification $(r=$ $0.18, \mathrm{p}<0.01)$, patriotism $(\mathrm{r}=0.27, \mathrm{p}<0.001)$ and nationalism $(\mathrm{r}=0.23, \mathrm{p}<0.001$, but negatively with internationalism $(\mathrm{r}=-0.22, \mathrm{p}<0.001)$ and cosmopolitanism $(\mathrm{r}=-0.25, \mathrm{p}<0.001)$. All three components of consumer ethnocentrism are only moderately correlated with each other $(r=0.27$ to $0.36, p<0.001)$, which confirms that the $\mathrm{CE}$ construct has three correlated but independent dimensions. Similar patterns of correlations are observed for the individual samples from the four countries.

$<$ Insert Table 3 about here $>$

Finally, predictive validity was tested using two sets of hierarchical multiple regression analyses, with consumer evaluations and behavioral intentions for five products and services as dependent variables. The first set used the mean-centered average scores for all the existing scales (CETSCALE, consumer animosity, national identification, patriotism, nationalism, internationalism and cosmopolitanism) as predictors followed by the revised CE Scale (CES) to assess its incremental effect on both the dependent variables. Similarly, the second set used mean-centered average scores for all the existing scales followed by the three sub-scales (AFR, COB and BEP) of the revised CE scale (CES), in order to examine their individual and incremental effects on both the dependent variables.

All the existing scales explained about $32-38 \%$ variance in the two dependent variables for all the products and services, while the revised CE scale explained an additional 16-24\% variance. Upon further 
investigation, it was found that among the existing scales, only the CETSCALE (9-12\%), patriotism (8$12 \%)$, and cosmopolitanism (10-14\%) explained a major proportion of variance in the two dependent variables; however none of these could match the revised CE scale (16-24\%). The revised CE scale (CES) outperformed all the existing scales in the first set of regression analyses for all the products and services, with significantly higher regression coefficients for consumer evaluations (domestic: $\beta=0.16$ to 0.42; foreign: $\beta=-0.19$ to -0.31 ) and behavioral intentions (domestic: $\beta=0.21$ to 0.33 ; foreign: $\beta=-0.22$ to -0.28). The three sub-scales of CES (AFR, COB and BEP) also show significantly higher regression coefficients and explain greater variance in both consumer evaluation and behavioral intentions. All the demographic variables together explain less than $5 \%$ variance in both the dependent variables. Finally, multicollinearity is not a major problem in this data as shown by the low VIF values $(<2)$.

\section{DISCUSSION AND CONTRIBUTION}

This research note makes a significant contribution by developing and validating a multidimensional revised CE scale (CES). First, it clarifies the conceptual definition of CE by reconceptualizing it as a three-dimensional attitude construct consisting of affective, cognitive and behavioral components. The affective component represents emotional reactions to domestic and foreign products and services as well as manufacturers and service providers. The cognitive component represents a cognitive bias favoring domestic products and services, and against products made in foreign countries or services provided by service providers from other countries. Finally, the behavioral component represents the tendency to favor domestic products and services over those from foreign countries. This three-dimensional structure addresses calls for a more comprehensive and meaningful structure for $\mathrm{CE}$ compared to the more simplistic unidimensional structures offered in prior research (Verlegh, 2007).

A three-dimensional structure for $\mathrm{CE}$ would help researchers delineate the unique influence of its affective, cognitive and behavioral components on consumer perceptions and evaluations towards domestic and foreign products and their manufacturers, services and their providers and even towards diverse countries and cultures as well. This is an important contribution because in many situations 
consumer may have very favorable emotions towards a particular country, which may affect their perceptions about its products and services; however, they may also have strong cognitive reasons (high price or poor quality) that may prevent them from buying, using or recommending these products and services. The revised CE scale (CES) will help international marketers explore these differences.

Second, this research tests and provides evidence about the face and construct validity of the revised CE scale (CES), its convergent and discriminant validity as well as its cross-cultural measurement invariance, using data from four countries with diverse cultural and socio-economic backgrounds. In this process, it addresses a long-standing gap for a cross-culturally equivalent multi-dimensional scale to measure $\mathrm{CE}$, which will be useful for researchers around the world to measure $\mathrm{CE}$ in a reliable and valid manner, albeit there is a need to further test and validate this new scale in other countries and cultures.

Third, the predictive validity of CES is tested by investigating its influence on five products and services, with varying levels of involvement, consumption context and purchase motivation. This is an important departure from most past studies that examine either a single product or choose many products without any strong conceptual justification. Hence it provides a more comprehensive view of the effect of CES and all the other scales. In this context, it is important to note that the revised CE scale (CES) explains greater variance compared to all the existing scales, as a whole as well as with its three components treated separately. This is an important contribution to the CE research because it would allow researchers to use this revised scale instead of using numerous other similar scales.

Fourth, the revised CE scale significantly improves Shimp and Sharma's (1987) unidimensional CETSCALE by reconceptualizing it as a multidimensional construct, which was their original intention as well. Moreover, despite its more complex three-dimensional structure the revised CE scale has only 18 items, which is quite similar to Shimp and Sharma's (1987) 17-item scale and yet it provides a much richer picture of this complex socio-psychological construct. Finally, this paper also provides evidence of nomological validity of this revised CE scale by showing the expected pattern of correlations with a broad range of existing scales used in prior research. 


\section{LIMITATIONS AND FUTURE RESEARCH}

This paper has a few limitations. First, both the studies reported in this paper use adult shoppers in only four countries with different cultures and levels of socio-economic development, however this may not be enough to generalize the cross-cultural invariance and predictive validity of this scale. Hence, future research around the world could include the revised CE scale in their studies to help further assess its cross-cultural validity and generalizability. Future research may also include other relevant constructs beyond the ones used in this research (e.g., animosity, patriotism, cosmopolitanism etc.) as well as other antecedents, mediators and moderators identified in prior research (e.g., Shankarmahesh, 2006), to further examine the revised CE Scale's convergent, discriminant, nomological, and predictive validity. Finally, as pointed out by the reviewers, the use of double-barreled items to tap into consumer ethnocentrism towards both 'products and services' may be problematic. Hence, future studies should split these items into subitems that address the products and services separately.

\section{REFERENCES}

Acharya, C. \& Elliott, G. 2003. Consumer Ethnocentrism, Perceived Product Quality and Choice - An Empirical Investigation. Journal of International Consumer Marketing, 15(4): 87-115.

Anderson, J. C. \& Gerbing, D. W. 1988. Structural equation modeling in practice: A review and recommended two step approach. Psychological Bulletin, 103(3): 411-23.

Ang, S. H., Jung, K., Kau, A. K., Leong, S. M., Pornpitakpan, C., \& Tan, S. J. 2004. Animosity towards economic giants: what the little guys think. Journal of Consumer Marketing, 21(3): 190-207.

Bagozzi, R. P. \& Yi, Y. 1988. On the evaluation of structural equation models. Journal of the Academy of Marketing Sciences, 16(1): 74- 84.

Balabanis, G., Diamantopoulos, A., Mueller, R. D., \& Melewar, T. C. 2001. The impact of nationalism, patriotism and internationalism on consumer ethnocentric tendencies. Journal of International Business Studies, 32(1): 157-75.

Bawa, A. 2004. Consumer Ethnocentrism: CETSCALE Validation and Measurement of Extent. Vikalpa, 29(3): 43-57.

Chryssochoidis, G., Krystallis, A., \& Perreas, P. 2007. Ethnocentric beliefs and country-of-origin (COO) effect Impact of country, product and product attributes on Greek consumers' evaluation of food products. European Journal of Marketing, 41(11/12): 2007. 
Cleveland, M., Laroche, M., \& Papadopoulos, N. 2009. Cosmopolitanism, Consumer Ethnocentrism, and Materialism. Journal of International Marketing, 17(1): 116-46.

Douglas, S. P. \& Nijssen, E. J. 2003. On the Use of 'Borrowed' Scales in Cross National Research: A Cautionary Note. International Marketing Review, 20(6): 621-42.

Durvasula, S., Andrews, J. C., \& Netemeyer, R. G. 1997. A cross-cultural comparison of consumer ethnocentrism in the United States and Russia. Journal of International Consumer Marketing, 9(4): 7393.

Eagly, A. H. \& Chaiken, S. 1993. The psychology of attitudes. Forth Worth, TX: Harcourt Brace Jovanovich College Publishers.

Fornell, C. \& Larcker, D. F. 1981. Evaluating Structural Equation Models with Unobservable Variables and Measurement Error. Journal of Marketing Research, 18(1): 39-50.

Good, L. K. \& Huddleston, P. T. 1995. Ethnocentrism and the Eastern European consumer: are feelings and intentions related? International Marketing Review, 12(5): 35-48.

Hardesty, D. M. \& Bearden, W. O. 2004. The use of expert judges in scale development: Implications for improving face validity of measures of unobservable constructs. Journal of Business Research, 57(2): 98107.

Hsu, J. L. \& Nien, H.-P. 2008. Who are ethnocentric? Examining consumer ethnocentrism in Chinese societies. Journal of Consumer Behaviour, 7(6): 436-47.

Hu, L.-t. \& Bentler, P. M. 1999. Cutoff criteria for fit indexes in covariance structure analysis: conventional criteria versus new alternatives. Structural Equation Modeling, 6(1): 1-55.

Jo, M.-S. 1998. Contingency and contextual issues of ethnocentrism pitched advertisements: A crossnational comparison. International Marketing Review, 15(6): 447-57.

Johansson, J. K., Ronkainen, I. A., \& Czinkota, M. R. 1994. Negative Country-of-Origin Effects: The Case of The New Russia. Journal of International Business Studies, 25(1): 157-76.

Khan, M. N. \& Rizvi, S. R. 2008. Consumer Ethnocentrism: Relevance and Implications for Marketers. ICFAI Journal of Consumer Behavior, 3(1): 52-65.

Kinra, N. 2006. The effect of country-of-origin on foreign brand names in the Indian market. Marketing Intelligence \& Planning, 24(1): 15-30.

Klein, J. G., Ettenson, R., \& Krishnan, B. C. 2006. Extending the construct of consumer ethnocentrism: when foreign products are preferred. International Marketing Review, 23(3): 304-21.

Klein, J. G., Ettenson, R., \& Morris, M. D. 1998. The animosity model of foreign product purchase: An empirical test in the People's Republic of China. Journal of Marketing, 62(1): 89-100.

Kwak, H., Jaju, A., \& Larsen, T. 2006. Consumer Ethnocentrism Offline and Online: The Mediating Role of Marketing Efforts and Personality Traits in the United States, South Korea, and India. Journal of the Academy of Marketing Science, 34(3): 367-85.

LaPiere, R. T. 1934. Attitudes vs. actions. Social forces, 13(2): 230-37. 
LeVine, R. A. \& Campbell, D. T. 1972. Ethnocentrism: Theories of Conflict, Ethnic Attitudes, and Group Behavior. New York: John Wiley \& Sons.

Marcoux, J.-S., Filiatrault, P., \& Chéron, E. 1997. The Attitudes Underlying Preferences of Young Urban Educated Polish Consumers Towards Products Made in Western Countries. Journal of International Consumer Marketing, 9(4): 5-29.

Netemeyer, R. G., Durvasula, S., \& Lichtenstein, D. R. 1991. A cross-national assessment of the reliability and validity of the CETSCALE. Journal of Marketing Research, 28(3): 320-27.

Nunnally, J. C. 1978. Psychometric Theory. New York, NY: McGraw Hill.

Pereira, A., Hsu, C.-C., \& Kundu, S. 2002. A cross-cultural analysis of ethnocentrism in China, India, and Taiwan. Journal of International Consumer Marketing, 15(1): 77-90.

Reardon, J., Miller, C., Vida, I., \& Kim, I. 2005. The effects of ethnocentrism and economic development on the formation of brand and ad attitudes in transitional economies. European Journal of Marketing, 39(7/8): 737-54.

Shankarmahesh, M. N. 2006. Consumer ethnocentrism: an integrative review of its antecedents and consequences. International Marketing Review, 23(2): 146-72.

Sharma, P. 2010. Cultural Influences on Consumer Ethnocentrism: A Multi-country Investigation. Journal of Euromarketing, 19(2\&3): 175-96.

Sharma, S., Shimp, T. A., \& Shin, J. 1995. Consumer ethnocentrism: A test of antecedents and moderators. Journal of the Academy of Marketing Science, 23(1): 26-37.

Shimp, T. A. \& Sharma, S. 1987. Consumer ethnocentrism: Construction and validation of the CETSCALE. Journal of Marketing Research, 24(3): 280-89.

Steenkamp, J.-B. E. M. \& Baumgartner, H. 1998. Assessing Measurement Invariance in Cross-National Consumer Research. Journal of Consumer Research, 25(1): 78-90.

Steenkamp, J.-B. E. M., Hofstede, F. t., \& Wedel, M. 1999. A Cross-National Investigation into the Individual and National Cultural Antecedents of Consumer Innovativeness. Journal of Marketing, 63(2): 55-69.

Suh, T. \& Kwon, I.-W. G. 2002. Globalization and reluctant buyers. International Marketing Review, 19(6): 663-80.

Supphellen, M. \& Grønhaug, K. 2003. Building foreign brand personalities in Russia: the moderating effect of consumer ethnocentrism. International Journal of Advertising, 22(2): 203-26.

Supphellen, M. \& Rittenburg, T. L. 2001. Consumer ethnocentrism when foreign products are better. Psychology and Marketing, 18(9): 907-27.

Teo, P.-C., Mohamad, O., \& Ramayah, T. 2011. Testing the dimensionality of Consumer Ethnocentrism Scale (CETSCALE) among a young Malaysian consumer market segment. African Journal of Business Management, 5(7): 2805-16. 
Upadhyay, Y. \& Singh, S. K. 2006. Preference for Domestic Goods: A Study of Consumer Ethnocentrism. Vision, 10(3): 59-68.

Vaughan, G. \& Hogg, M. A. 2005. Introduction to social psychology. Australia: Pearson Education.

Verlegh, P. W. J. 2007. Home country bias in product evaluation: the complementary roles of economic and socio-psychological motives. Journal of International Business Studies, 38(3): 361-73.

Wheaton, B., Muthen, B., Alwin, D. F., \& Summers, G. F. 1977. Assessing reliability and stability in panel models.In R., Heise D., (Ed.), Sociological methodology. San Francisco: Jossey-Bass. 
Table 1 - Model Comparison for Measurement Invariance (Study 2)

\begin{tabular}{lcccccc}
\hline Model Description * & $\chi^{2}$ & $d f$ & $\chi^{2} / d f$ & RMSEA & SRMR & CFI \\
\hline Full configural invariance & $\mathbf{9 6 3 . 7 9}$ & $\mathbf{5 2 8}$ & $\mathbf{1 . 8 3}$ & $\mathbf{. 0 4 2}$ & $\mathbf{. 0 5 8}$ & $\mathbf{. 9 7}$ \\
Full metric invariance & 1232.34 & 588 & 2.10 & .054 & .063 & .93 \\
Partial metric invariance & $\mathbf{1 0 2 1 . 2 9}$ & $\mathbf{5 7 6}$ & $\mathbf{1 . 7 7}$ & $\mathbf{. 0 4 4}$ & $\mathbf{. 0 6 1}$ & $\mathbf{. 9 6}$ \\
Full scalar invariance & 1358.67 & 636 & 2.14 & .057 & .068 & .92 \\
Partial scalar invariance & $\mathbf{1 0 7 3 . 2 8}$ & $\mathbf{6 2 4}$ & $\mathbf{1 . 7 2}$ & $\mathbf{. 0 4 5}$ & $\mathbf{. 0 6 3}$ & $\mathbf{. 9 5}$ \\
Full factor covariance invariance & $\mathbf{1 0 8 9 . 5 2}$ & $\mathbf{6 3 6}$ & $\mathbf{1 . 7 1}$ & $\mathbf{. 0 4 6}$ & $\mathbf{. 0 6 4}$ & $\mathbf{. 9 4}$ \\
Full factor error variance invariance & $\mathbf{1 1 0 3 . 4 3}$ & $\mathbf{6 4 8}$ & $\mathbf{1 . 7 0}$ & $\mathbf{. 0 4 7}$ & $\mathbf{. 0 6 5}$ & $\mathbf{. 9 3}$ \\
Full error variance invariance & 1322.56 & 720 & 1.84 & .056 & .077 & .90 \\
Partial error variance invariance & $\mathbf{1 1 4 8 . 8 6}$ & $\mathbf{7 0 4}$ & $\mathbf{1 . 6 3}$ & $\mathbf{. 0 4 8}$ & $\mathbf{. 0 5 9}$ & $\mathbf{. 9 2}$ \\
\hline
\end{tabular}

* Rows with data in bold show the supported invariance models. 
Table 2: Revised Consumer Ethnocentrism Scale (CES)

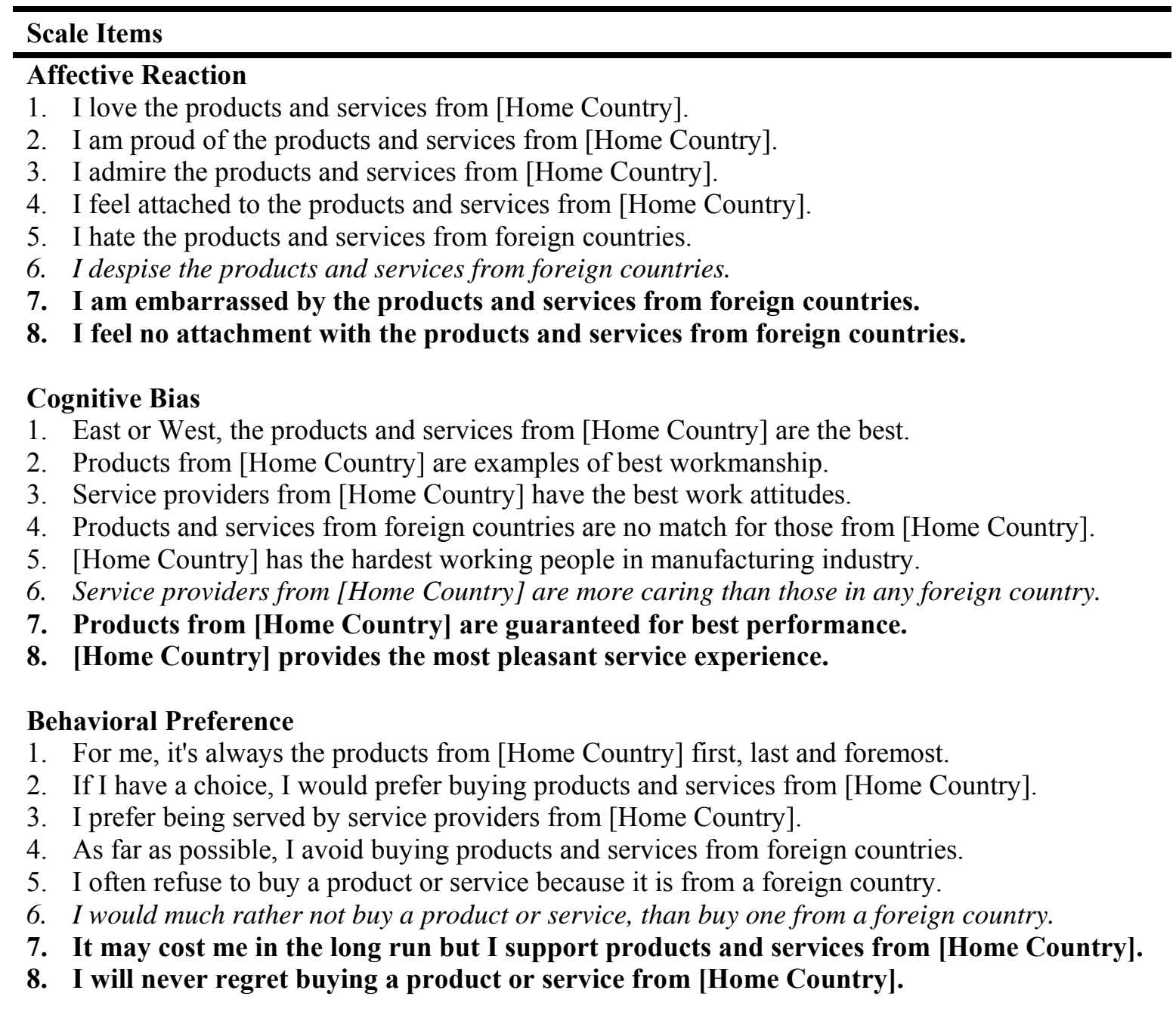

Notes: 1) Items in bold were dropped due to low factor loadings and item-to-total correlations. 2) Items in italics do not show metric invariance (equal factor loadings) across the four groups. 
Table 3 - Correlation Matrix (Study 2)

\begin{tabular}{|c|c|c|c|c|c|c|c|c|c|c|c|}
\hline Scale/Sub-scales & $\begin{array}{c}1 \\
\text { CES }\end{array}$ & $\begin{array}{c}2 \\
\text { AFR }\end{array}$ & $\begin{array}{c}3 \\
\text { COB }\end{array}$ & $\begin{array}{c}4 \\
\text { BEP }\end{array}$ & $\begin{array}{c}5 \\
\text { CET }\end{array}$ & $\begin{array}{c}6 \\
\text { CAN }\end{array}$ & $\begin{array}{c}9 \\
\text { NID }\end{array}$ & $\begin{array}{c}10 \\
\text { PAT }\end{array}$ & $\begin{array}{c}11 \\
\text { NAT }\end{array}$ & $\begin{array}{c}12 \\
\text { INT }\end{array}$ & $\begin{array}{c}13 \\
\mathrm{COS}\end{array}$ \\
\hline 1. Consumer Ethnocentrism (CES) & .88 & & & & & & & & & & \\
\hline 2. Affective Reaction (AFR) & $.62^{* * *}$ & .84 & & & & & & & & & \\
\hline 3. Cognitive Bias (COB) & $.68^{* * *}$ & $.27^{* * *}$ & .86 & & & & & & & & \\
\hline 4. Behavioral Preference (BEP) & $.72^{* * *}$ & $.33^{* * *}$ & $.36^{* * *}$ & .82 & & & & & & & \\
\hline 5. CETSCALE (CET) & $.42^{* * *}$ & $.34^{* * *}$ & $.37^{* * *}$ & $.42^{* * *}$ & .77 & & & & & & \\
\hline 6. Consumer Animosity (CAN) & $.14^{* *}$ & $.17^{* *}$ & $.15^{* *}$ & .06 & $.10^{*}$ & .74 & & & & & \\
\hline 7. National Identification (NID) & $.27^{* * *}$ & $.29^{* * *}$ & $.23^{* * *}$ & $.24^{* * *}$ & $.18^{* *}$ & $.15^{* *}$ & .81 & & & & \\
\hline 8. Patriotism (PAT) & $.23^{* * *}$ & $.25^{* * *}$ & $.21^{* * *}$ & $.20^{* * *}$ & $.19^{* *}$ & $.24^{* * *}$ & $.48^{* * *}$ & .73 & & & \\
\hline 9. Nationalism (NAT) & $.32^{* * *}$ & $.36^{* * *}$ & $.30^{* * *}$ & $.33^{* * *}$ & $.27^{* * *}$ & $.21^{* *}$ & $.54^{* * *}$ & $.52^{* * *}$ & .72 & & \\
\hline 10. Internationalism (INT) & $-.22^{* * *}$ & $-.27^{* * *}$ & $-.20^{* * *}$ & $-.21^{* * *}$ & $-17^{* *}$ & $-.13^{*}$ & $-.21^{* *}$ & $-.23^{* * *}$ & $-.36^{* * *}$ & .68 & \\
\hline 11. Cosmopolitanism (COS) & $-.25^{* * *}$ & $-.19^{* * *}$ & $-.22^{* * *}$ & $-.28^{* * *}$ & $-.15^{* * *}$ & -.05 & $-.24^{* * *}$ & $-.27^{* * *}$ & $-.33^{* * *}$ & $.45^{* * *}$ & .72 \\
\hline Average Variance Extracted & .62 & .63 & .62 & .61 & .54 & .52 & .59 & .51 & .51 & .46 & .51 \\
\hline
\end{tabular}

Note: Figures in bold italics on the diagonal are the composite reliabilities for each scale/sub-scale.

$* p<.05, * * p<.01, * * * p<.001$ 